\title{
Long term (?) effects of withholding superphosphate application on North Island hill country: a 10-year update
}

\author{
M.B. DODD and S.F. LEDGARD \\ AgResearch, Ruakura Research Centre, Private Bag 3123, Hamilton
}

\begin{abstract}
Measurements of soil phosphate, pasture production and botanical composition from two superphosphate fertiliser trials in northern North Island hill country (Whatawhata and Te Kuiti) have been made over a 15 -year period. The impacts of superphosphate fertiliser withholding have included a decline in Olsen $\mathrm{P}$, decreases in annual pasture production of $10-17 \%$ (Whatawhata) and $22-42 \%$ (Te Kuiti), decreases in the abundance of productive and desirable species (15-20\% for ryegrass and white clover), and increases in the abundance of undesirable species (browntop and other low fertility grasses). These changes have increased over time, beyond that period covered by the original experiments (4-6 years). Different responses to withholding between the two sites are still apparent, and the reasons for these are explored. It is not clear that these systems have yet reached a new equilibrium, nor how long it will take for this to happen. The implications for our view of longterm grassland studies are discussed.
\end{abstract}

Keywords: fertiliser, long-term, pasture production, pasture species composition

\section{Introduction}

During the mid-1980s, the withdrawal of subsidies for farm inputs led to a substantial reduction in fertiliser use in hill country. To investigate the likely impacts of this trend on agricultural productivity, experiments on fertiliser withholding were initiated at Whatawhata Research Centre, Te Kuiti Hill Country Research Station and Ballantrae Hill Country Research Station. The results of these experiments after 4-7 years were subsequently published in the proceedings of the New Zealand Grassland Association (Gillingham et al. 1990; O'Connor et al. 1990; Lambert et al. 1990; Clark et al. 1990).

In terms of the effect of withholding fertiliser on key farm system parameters, a number of consistent conclusions could be drawn from the three studies. Soil Olsen P levels decreased where previous levels of $\mathrm{P}$ input had been relatively high, but remained static where previous levels of $\mathrm{P}$ input had been relatively low. The abundance of pasture species such as browntop, weeds and moss increased. Annual pasture production decreased - relatively more on easy slopes and where previous levels of $\mathrm{P}$ input had been high. The levels of all measures of animal production (including grazing days, ewe liveweights, lamb weaning weights, ewe and lamb fleeceweights) also decreased by $1-4 \%$ per year for each year following the cessation of fertiliser application.

However, there were a number of important differences in the responses of the individual sites to the fertiliser withholding treatments. The pasture production decline at Whatawhata was less than that of the other two sites. For example, comparing similar treatments across sites, the decline from withholding $250 \mathrm{~kg}$ super/ha/year over 4 years was $9 \%$ at Whatawhata compared with $18 \%$ at Te Kuiti, and the decline from withholding $500 \mathrm{~kg}$ super/ha/year over 4 years was $14 \%$ at Whatawhata compared with $18 \%$ at Ballantrae. Declines in ryegrass and white clover content, which would be expected to be key indicators of fertility status, were surprisingly not consistent across sites. A significant decrease in ryegrass content was observed only at Whatawhata and Ballantrae, and a significant decrease in white clover content was observed only at Te Kuiti.

In the almost 10 years since the publication of these studies, the fertiliser treatments have continued at Whatawhata and Te Kuiti, and measurements of soil and pasture parameters have continued to be made. The objectives of this paper are to explore the reasons for the site differences originally noted, present an update on the measurements that contain some new insights, and discuss the value of such sites as long term monitoring tools.

\section{Methods}

Details of the original establishment and maintenance of the fertiliser withholding trials at Whatawhata and Te Kuiti are given in Gillingham et al. (1990) and O'Connor et al. (1990). At Whatawhata, five superphosphate fertiliser rates $(10,20,30,50$ and $100 \mathrm{kgP} /$ ha/year) had been applied to 20 different paddocks in a block of northwesterly aspect incorporating steep and 
easy contours. In 1984 the fertiliser additions ceased on two of the paddocks in each treatment, creating the withholding treatment referred to as 'residual' (compared with continuity of fertiliser addition on 'maintenance' paddocks). From 1989, triple superphosphate was applied instead of single superphosphate. The measurements from 1984-1988 reported in Gillingham et al. (1990) included Olsen P soil tests, pasture production from caged plots, pasture species composition from both caged plots and grazed transects, and annual sheep grazing days. Since then, Olsen P has been measured in 1991, 1993, 1994, 1995 and 1999, and the same transects were measured for species composition in 1989, 1991 and 1997. The methodology of these measurements was consistent with the original trial measurements. In addition, pasture production was measured from May 1998-April 1999 by harvesting caged plots in the 10,20 and $50 \mathrm{kgP} /$ ha treatments (both maintenance and residual). In each of these paddocks, 10 representative sites were identified and cages rotated around a plot marker throughout the year. In total, eight harvests were made on the sites. At each harvest a subsample was taken for dissection into ryegrass, browntop, paspalum, carpet grass, other grasses, white clover, other legumes, weeds and moss.

At Te Kuiti, $250 \mathrm{~kg}$ super/ha/year had been applied to a block that included northerly and southerly aspects, and easy and steep contours. In 1983 the block was split into two farmlets of six paddocks each where the fertiliser input was maintained on one farmlet, and on the other it was withheld. The measurements from 1983-1988 reported in O'Connor et al. (1990) included Olsen P soil tests, pasture production from both caged plots and visual cover assessments, pasture species composition from grazed transects, ewe and lamb liveweights, wool weights and wool quality. Since then, soil Olsen P and pasture species composition on grazed transects were measured annually from 1989-1997 and pasture production from caged plots has been measured in 1992 93, 1993-94 and 1996-97. The pasture production data from 1992-94 was reported by Roach et al. (1996). The methodology using transect measurements was consistent with the original trial measurements, and with those at the Whatawhata site. Detailed pasture composition measurements by weight were not measured at Te Kuiti. Instead, the legume component of the harvested pasture was separated and its contribution to productivity measured.

\section{Results}

\section{Whatawhata trial}

During the 15 years of measurement, there were no significant differences in Olsen $\mathrm{P}$ between the main- tenance and residual treatments at the 10, 20 and 30 $\mathrm{kgP} / \mathrm{ha}$ fertiliser rates (data for $20 \mathrm{kgP} / \mathrm{ha}$ rate shown in Figure 1). In addition, these treatments had little impact on Olsen $\mathrm{P}$, which remained between 10-15 units over the whole period. However, at the $50 \mathrm{kgP} /$ ha rate (and $100 \mathrm{kgP} /$ ha rate - data not shown), the maintenance treatment significantly increased soil Olsen P from 1985 onwards (Figure 1). Soil Olsen P tests were similar on steep and easy slopes, and mean data only is presented in Figure 1.

In the first 4 years of the trial at Whatawhata (198488 ), the only significant effect of withholding fertiliser was a $14 \%$ relative decline in annual pasture production on easy country where the paddocks had a history of high fertiliser inputs (Table 1). However by year 15, a significant decline of up to $16 \%$ was evident on the easy slopes under all fertiliser rate treatments. At this stage a relative decline of $17 \%$ was also observed on the steep slopes with a history of high fertiliser inputs.

The measurements of species abundance made on the permanent transects over 15 years show changes in the abundance of ryegrass and white clover (Figure 2). There is now a $15 \%$ lower abundance of both ryegrass and white clover in the residual treatment compared with the maintenance treatment. Consistently significant differences between the two treatments have emerged from 1987 (year 5) onwards for ryegrass and from 1991 (year 9) onwards for white clover.

The measurements of species composition by weight made in October of 1998 also showed these differences (Table 2). The greatest impact of withholding superphosphate fertiliser on ryegrass content has been a reduction of 17 percentage points on easy slopes where the paddocks had a history of low rates of fertiliser. These paddocks also have the greatest reductions in white clover content. By contrast, significant increases in other grass (excluding browntop) and weed content

Figure 1 Effect of withholding treatments on soil Olsen $P$ at Whatawhata (bars represent SED). SP = superphosphate originally applied at $P$ rate $(\mathrm{kg} / \mathrm{ha})$ indicated; $R=$ residual; $\mathrm{M}=$ maintenance.

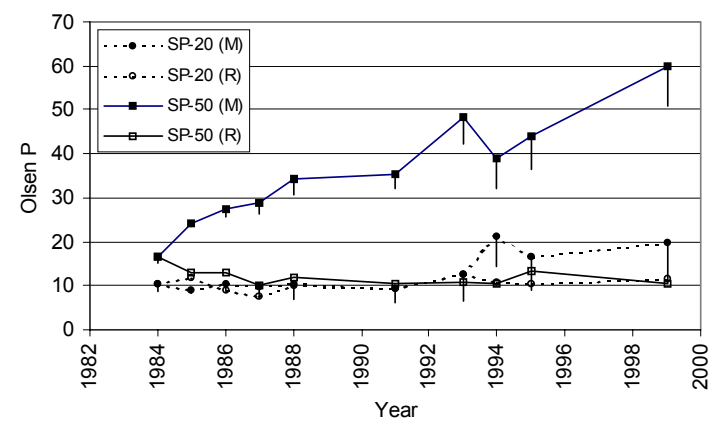


Table 1 Effect of withholding superphosphate on annual pasture production (data is the difference between residual and maintenance treatments expressed as a $\%$ of maintenance treatments). $\mathrm{SP}=$ superphosphate originally applied at $P$ rate $(\mathrm{kg} / \mathrm{ha})$ indicated by subscript.

\begin{tabular}{|c|c|c|c|c|c|c|c|c|}
\hline Treatments & \multicolumn{2}{|c|}{ Year 1} & \multicolumn{2}{|c|}{ Year 4} & \multicolumn{2}{|c|}{ Year 10} & \multicolumn{2}{|c|}{ Year 15} \\
\hline \multicolumn{9}{|c|}{ Whatawhata north easy } \\
\hline $\mathrm{SP}_{10}$ & -9 & NS & -2 & NS & & & -16 & ** \\
\hline $\mathrm{SP}_{20}$ & -12 & NS & -8 & NS & & & -16 & $* *$ \\
\hline $\mathrm{SP}_{50}$ & -14 & $* *$ & -14 & $* *$ & & & -10 & * \\
\hline \multicolumn{9}{|c|}{ Whatawhata north steep } \\
\hline $\mathrm{SP}_{10}$ & 13 & NS & 4 & NS & & & 0 & NS \\
\hline $\mathrm{SP}_{20}$ & 5 & NS & -8 & NS & & & -12 & NS \\
\hline $\mathrm{SP}_{50}$ & 21 & NS & 4 & NS & & & -17 & ** \\
\hline \multicolumn{9}{|l|}{ Te Kuiti $\left(\mathrm{SP}_{22}\right)$} \\
\hline North easy & & & & & & & -29 & \\
\hline North steep & $1-7$ & NS & $1-18$ & $* *$ & $1-29$ & $* *$ & -42 & $* *$ \\
\hline South easy & & & & & & & -22 & $*$ \\
\hline South steep & & & & & & & -29 & $* *$ \\
\hline average of & & & & & & & & \\
\hline not signific & 0.05 & & 0.01 & & & & & \\
\hline
\end{tabular}

Figure 2 Effect of withholding treatments on ryegrass and white clover abundance at Whatawhata - mean of all fertiliser rate treatments (bars represent $S E D$ ). $R=$ residual; $M=$ maintenance.

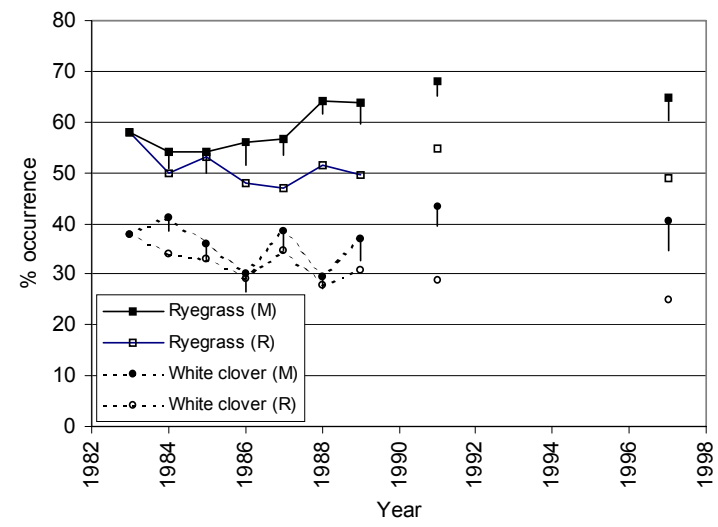

Table 2 Effect of withholding superphosphate on pasture species composition (\% by weight) in October $1998 . \mathrm{R}=$ residual; $\mathrm{M}=$ maintenance; $\mathrm{SP}=$ superphosphate originally applied at $\mathrm{P}$ rate $(\mathrm{kg} / \mathrm{ha})$ indicated by subscript.

\begin{tabular}{|c|c|c|c|c|c|c|c|c|c|c|c|c|}
\hline \multirow[b]{2}{*}{ Treatments } & \multicolumn{3}{|c|}{--- Ryegrass --- } & \multicolumn{3}{|c|}{--- Other grasses --- } & \multicolumn{3}{|c|}{--- White clover --- } & \multicolumn{3}{|c|}{--- Weeds --. } \\
\hline & $\mathrm{R}$ & $\mathrm{M}$ & & $\mathrm{R}$ & M & & $\mathrm{R}$ & M & & $\mathrm{R}$ & $\mathrm{M}$ & \\
\hline \multicolumn{13}{|c|}{ Whatawhata north easy } \\
\hline $\mathrm{SP}_{10}$ & 19 & 36 & ** & 39 & 33 & NS & 1 & 3 & + & 13 & 13 & NS \\
\hline $\mathrm{SP}_{20}$ & 17 & 34 & $* *$ & 37 & 25 & NS & 1 & 6 & ${ }^{* \star}$ & 18 & 20 & NS \\
\hline $\mathrm{SP}_{50}$ & 34 & 40 & NS & 27 & 28 & NS & 3 & 2 & NS & 15 & 15 & NS \\
\hline \multicolumn{13}{|c|}{ Whatawhata north steep } \\
\hline $\mathrm{SP}_{10}$ & 8 & 14 & NS & 48 & 38 & NS & 1 & 2 & NS & 10 & 17 & NS \\
\hline $\mathrm{SP}_{20}$ & 5 & 9 & NS & 57 & 35 & $* *$ & 1 & 2 & NS & 6 & 17 & $*$ \\
\hline $\mathrm{SP}_{50}$ & 5 & 15 & + & 54 & 42 & + & 2 & 2 & NS & 9 & 17 & + \\
\hline
\end{tabular}

${ }^{\text {NS }}$ not significant; ${ }^{+}=p<0.10 ;{ }^{*}=p<0.05 ;{ }^{* *}=p<0.01$

were only evident on steep paddocks at the two higher fertiliser rate treatments. On these paddocks other grasses were a larger component, and weeds a smaller component, in the residual relative to maintenance treatments. There were no significant differences between the residual and maintenance treatments for browntop and other legumes. There was a significant difference between the two treatments for $\mathrm{C}_{4}$ grasses (paspalum + carpet grass), which averaged $2.6 \%$ on residual and $0.5 \%$ on maintenance paddocks. The peak contribution of these two $\mathrm{C}_{4}$ species occurred in early March, when they were $23 \%$ and $7 \%$ of pasture species composition for residual and maintenance paddocks respectively.

\section{Te Kuiti trial}

The continued application of superphosphate at $250 \mathrm{~kg} /$ ha/y appears to have had the desired effect of maintaining soil Olsen P at or slightly above the original value of 15 in 1983 (Figure 3). However, there has been a significant decline on the residual farmlet down to a level of approximately 5 in 1995.

While there was no significant relative decrease in pasture production from withholding fertiliser in the first year of the trial at Te Kuiti, in all subsequent years the relative loss in pasture production in the residual treatment was highly significant (Table 1). After 4 years, the average loss over all slope classes was $18 \%$, after 10 years $29 \%$ and after 15 years $31 \%$, representing a gradual decrease in the marginal loss per year over time. The data from 1996-97 indicate that the losses were greater on north aspects and steep slopes.

The measurements made on the permanent transects show little change in the abundance of ryegrass over the whole farmlet for the first 10 years, but thereafter a substantial increase in the maintenance treatment compared to the residual treatment (Figure 4). The abundance of white clover has been relatively variable 
over the 15-year period, but on average has increased in the maintenance treatment and changed little in the residual treatment (Figure 4). There is now a $20 \%$ difference in both ryegrass and white clover abundance in the maintenance treatment compared with the residual treatment. Consistently significant differences between the two treatments have emerged from 1993 (year 11) onwards for ryegrass and from 1985 (year 3) onwards for white clover.

The legume productivity data from the 1996-97 harvests show that the effect of withholding fertiliser in reducing legume content and production appeared to be greater on north aspects, as it was for total productivity (Table 3). However, the productivity of the legume component was reduced relatively more (mean of all slope classes $=70 \%$ ) by the withholding treatment than was total DM productivity.

Table 3 Effect of withholding superphosphate on annual legume $\%$ by weight and legume production ( $\%$ difference of residual treatments relative to maintenance treatments) at Te Kuiti (1996-97). $\mathrm{R}=$ residual; $\mathrm{M}=$ maintenance.

\begin{tabular}{|c|c|c|c|c|}
\hline \multirow[b]{2}{*}{ Treatment } & \multicolumn{3}{|c|}{--- Legume\% --- } & \multirow{2}{*}{$\begin{array}{l}\text { Legume DM difference } \\
\qquad \%\end{array}$} \\
\hline & $\mathrm{R}$ & $\mathrm{M}$ & & \\
\hline North easy & 6 & 15 & * & -75 \\
\hline North steep & 4 & 16 & * & -84 \\
\hline South easy & 8 & 15 & * & -52 \\
\hline South steep & 8 & 16 & * & -68 \\
\hline
\end{tabular}

\section{Discussion}

The consensus at the Wanganui conference was that withholding fertiliser was a reasonable short-term strategy for coping with periods of low product prices relative to fertiliser costs (Clark et al. 1990). However in the long term, the sustainability of production is clearly jeopardised. The effects on soil P, losses in production and changes in botanical composition as a result of withholding fertiliser from the two hill country farmlets studied have increased over time. The initial conclusion from the Te Kuiti site after 3-6 years was that the pasture production level of the residual farmlets had stabilised at about $80 \%$ of that from the maintenance farmlets (O'Connor et al. 1990). The more recent data presented here and in Roach et al. (1996) indicate that a further relative reduction has occurred, to a level of approximately $70 \%$. At the Ballantrae site, a similar level of reduction (to approximately 68\%) had been reached under a high fertiliser/no fertiliser regime after only 7 years (Lambert et al. 1990). More recent data from Ballantrae indicated a relative reduction to
Figure 3 Effect of withholding treatments on average farmlet soil Olsen $\mathrm{P}$ at Te Kuiti (bars represent SED).

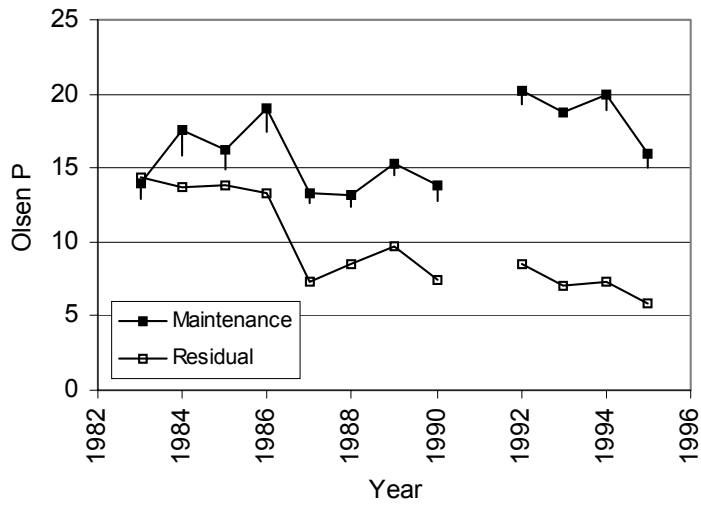

Figure 4 Effect of withholding treatments on ryegrass and white clover abundance at Te Kuiti (bars represent SED).

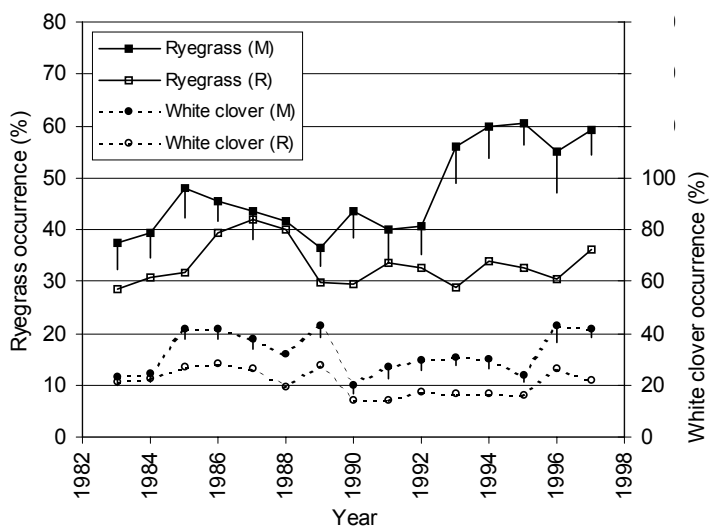

approximately $74 \%$ after 14 years (Lambert et al. 1996). At Whatawhata, the conclusion of Gillingham et al. (1990) was that production was "little affected" by fertiliser withholding. Although the magnitudes of the effects at this site continue to be less than those of the Te Kuiti site, they do appear to be increasing, and growing in significance across the range of treatments applied.

The observed trends in soil $\mathrm{P}$ were broadly consistent with between-site differences in withholding effects on pasture production. The decline in Olsen P under the residual treatment was quite marked at Te Kuiti, but largely absent at Whatawhata for similar fertiliser rates, even though the two sites began at a similar level (approximately 15 units). Thus the soils at Whatawhata appear to have lower inorganic P losses, perhaps driven by differences in soil $\mathrm{P}$ retention characteristics or immobilisation into organic $\mathrm{P}$ forms (Perrot et al. 1992). It should be noted that soil sulphate 
tests at both sites indicated similar levels of 7-8 units, suggesting that between-site differences in $\mathrm{S}$ as a result of superphosphate withholding were not an important factor.

Another possible explanation for the lesser effect of fertiliser withholding on pasture production at Whatawhata relates to the $\mathrm{C}_{4}$ component of the pastures there, a component largely absent from both the Te Kuiti and Ballantrae sites. The dominant $\mathrm{C}_{4}$ species concerned, paspalum and carpet grass, comprise a substantial proportion of pasture dry matter on northerly aspects during the summer and autumn at Whatawhata. Their abundance is no doubt related to the fact that Whatawhata is the most northerly site of the three, and experiences more severe summer dry conditions than the other two sites. The combination of moisture limitations to the growth of well-fertilised pastures on northerly aspects, and the presence of summer-active species tolerant of lower soil fertility (e.g., Henskens 1997), may mean that the relativity between the production of high and low fertility pastures is not so great as at other sites.

The likely impacts of the deterioration in species composition on farm systems are important. The shift from ryegrass to browntop-dominant pastures with a significant $\mathrm{C}_{4}$ component, and the drop in legume content in proportion to total production, will result in a change in the seasonal pattern of pasture growth and lower feed quality. Both of these effects will limit the ability to finish animals and will move the system towards carrying more store stock.

Overall, the results from these trials question our understanding of the phrase "long-term". At the time of the Wanganui conference, perhaps the phrase was more a reflection of the contemporary farm planning horizon. The economic climate was such that farms previously applying fertiliser on an annual basis were considering withholding application for up to 5 years. The increase in the environmental awareness of the agricultural community over the last $10-15$ years has modified our perception of what it means to be thinking long-term. In the context of the sustainability of agricultural enterprises on hill country, the phrase "longterm" has quite a different meaning. The question mark in the title of this paper is a reflection that even a period of 15 years is an insufficient conceptual time frame. So few of our research projects have a truly long-term focus, and so few of our research sites have long-term data, that it is vital that we maintain those that do. Already, the Te Kuiti site has been lost to the research community through lack of funding, and the tenure of the Whatawhata site is uncertain. The current efforts to establish environmental monitoring sites in grassland systems are vital in this respect.

\section{Conclusions}

Pasture measurements on farmlets where fertiliser has been withheld for 15 years show that changes in dry matter production and botanical composition are continuing to occur. These changes include reduction in annual pasture production, decreases in productive and desirable species (ryegrass and white clover) and increases in undesirable species (browntop and other low fertility grasses). It is not clear whether these systems have reached a new equilibrium, nor how long it will take for this to happen.

\section{ACKNOWLEDGEMENTS}

Numerous current and former AgResearch staff have been involved in the collection of data that contributed to this paper, including Ellen Botting, Kevin Jones, Alec McGowan, Steve Orr, Ian Power, Chris Roach, Charlie Smart, Ian Tarbotton and Linda Trolove.

\section{REFERENCES}

Clark, D.A.; Ledgard, S.F.; Lambert, M.G.; O'Connor, M.B.; Gillingham, A.G. 1990. Long term effects of withholding phosphate application on North Island hill country: Economics. Proceedings of the New Zealand Grassland Association 51: 29-34.

Gillingham, A.G.; Richardson, S.; Power, I.L.; Riley, J. 1990. Long term effects of withholding phosphate application on North Island hill country: Whatawhata Research Centre. Proceedings of the New Zealand Grassland Association 51: 11-16.

Henskens, F.L.F. 1997. The biology and management of Axonopus affinis (Chase) in Australian pastures. Australian journal of agricultural research 48: 1219-1230.

Lambert, M.G.; Barker, D.J.; Mackay, A.D.; Springett, J. 1996. Biophysical indicators of sustainability of North Island hill pasture systems. Proceedings of the New Zealand Grassland Association 57: 31-36.

Lambert, M.G.; Clark, D.A.; Mackay, A.D. 1990. Long term effects of withholding phosphate application on North Island hill country: Ballantrae. Proceedings of the New Zealand Grassland Association 51: 2528.

O’Connor, M.B.; Smart, C.E.; Ledgard, S.F. 1990. Long term effects of withholding phosphate application on North Island hill country: Te Kuiti. Proceedings of the New Zealand Grassland Association 51: 2124.

Perrot, K.W.; Sarathchandra, S.U.; Dow, B.W. 1992. Seasonal and fertiliser effects on the organic cycle and microbial biomass in a hill country soil under 
pasture. Australian journal of soil research 30: 383394.

Roach, C.G.; Nemaia, E.K.K.; Ledgard, S.F.; Brier, G.J.; McLay, C.D.A. 1996. Effects of long-term differences in fertiliser history on hill country: seasonal pasture production, legume growth and phosphorus status. Proceedings of the New Zealand Grassland Association 57: 105-109. 